\title{
The Relationship Of Insulin-Like Growth Factor 1 With Bone Mass In Obese Female
}

\author{
Adek Ardiansyah ${ }^{1}$, Lilik Herawati1 ${ }^{1,2}$, Damayanti Tinduh ${ }^{3 *}$ \\ ${ }^{1}$ Sport Health Science, Faculty of Medicine Universitas Airlangga, Surabaya, Indonesia \\ ${ }^{2}$ Department of Physiology, Faculty of Medicine Universitas Airlangga, Surabaya, Indonesia \\ ${ }^{3}$ Physical Medicine and Rehabilitation Department, Faculty of Medicine Universitas Airlangga/Dr. Soetomo \\ General Hospital, Surabaya, Indonesia \\ *damayanti.tinduh@fk.unair.ac.id
}

\begin{abstract}
Obesity causes peripheral insulin resistance and hyperinsulinaemia, which causes a decrease in the secretion of Growth Hormone $(\mathrm{GH})$ and Insulin-like Growth Factors 1 (IGF-1). Decreased GH and IGF-1 secretion decreases bone mineral density (BMD) and increases the risk of fractures. This study aimed to analyze the relationship of insulin-like growth factor 1 with bone mass in obese female. This study used a cross sectional study method using 30 obese female aged 19-23 years, body mass index (BMI) $25-35 \mathrm{~kg} / \mathrm{m}^{2}$, normal blood pressure, normal resting heart rate (RHR), normal hemoglobin $(\mathrm{Hb})$ and fasting blood glucose $(\mathrm{FBG})<100 \mathrm{mg} / \mathrm{dL}$. Measurement of IGF-1 levels used the Enzym Link Immunosorbent Assay (ELISA) method. Measurement of bone mass using TANITA (Body Composition Analyzer DC3607601 (2) -1604 FA, TANITA Corporation of America, Inc., USA). The data analysis technique used the Pearson product-moment test with Statistical Package for Social Science (SPSS). The results showed that mean levels of IGF-1 $(1.17 \pm 0.10) \mathrm{ng} / \mathrm{mL}$ and bone mass $(2.49 \pm 0.06) \mathrm{kg}(r=0.712, p \leq 0.001)$. Our findings suggest that there was a positive correlation between IGF-1 levels and bone mass in obese female.
\end{abstract}

Keywords : IGF-1 levels, Bone Mass, Obesity

Received August 7, 2020; Revised August 30, 2020; Accepted September 23, 2020

STRADA Jurnal Ilmiah Kesehatan, its website, and the articles published there in are licensed under a Creative Commons Attribution-ShareAlike 4.0 International License.

\section{BACKGROUND}

Obesity is a condition that exceeds a person's relative body weight as a result of accumulation of nutrients, especially carbohydrates, fats and proteins. Obesity is currently a worldwide problem (Ayu and Handayani, 2016). Therefore, obesity is a dangerous condition. This is supported by the prevalence of obesity of $\sim 20 \%$ (Pasquali et al., 2020). According to the World Health Organization (WHO) in 2014, the prevalence of overweight at over 18 years of age reached $39 \%$, where $15 \%$ were female. This prevalence increased 2 times greater than the prevalence of obesity in 1980. According to WHO (2016), more than 1.9 billion people aged over 18 years are overweight and 600 million of them are obese. The high prevalence makes obesity a problem in the world.

Obesity is a risk factor for various health problems that are usually experienced by adults such as diabetes mellitus, hypertension and high cholesterol. The causes of obesity are very complex in the sense that there are many factors that cause obesity, such as 


\section{STRADA Jurnal Ilmiah Kesehatan}

DOI: $10.30994 /$ sjik.v9i2.423

ISSN: 2252-3847 (print); 2614-350X (online)

Vol.9 No.2 November 2020 Page.1041-1046

environmental, genetic, psychological, health, drugs, development and physical activity. The cause of obesity is multi-factorial, thus the food intake factor is one of many factors. Influential food intake is one that contains fat and is high in calories. Some of the factors that cause obesity include a history of obesity in the elderly, lack of consumption of vegetables and fruit and smoking habits (Dewi, 2015).

Obesity experiences hyperinsulinemia condition due to peripheral insulin resistance which causes reduced growth hormone $(\mathrm{GH})$ secretion. The resulting decrease in GH can inhibit the liver from secreting IGF-1 (Lewitt et al., 2014). Growth hormone (GH) and its physiological mediator, insulin-like growth factor-1 (IGF-1), have a major role in bone growth. In general, the effect of GH promoting linear growth appears to depend on the production of IGF-1 and possibly other IGF peptides. IGF-1 acts on cartilage, stimulates cell proliferation and synthesis of Deoxyribo Nucleic Acid (DNA), Ribonucleic Acid (RNA), proteins and proteoglycans. IGF-1 is a major component of the organic skeleton matrix and is the most important differentiating factor for osteoblasts. If there is a decrease in the secretion of GH and IGF-1, it can reduce bone mineral density (BMD) and increase the risk of fracture (Ekbote et al., 2015). According to research conducted by Chalista et al. (2017) that there is a relationship between IGF-1 and low bone mineral density in the elderly. However, the relationship between IGF-1 and bone mineral density in obesity is unclear. On the basis of the above background, the researchers wanted to find out whether there was a relationship between IGF-1 and bone mass in obese female.

\section{METHODS}

This study used a cross sectional study method using 30 obese female aged 19-23 years, body mass index (BMI) $25-35 \mathrm{~kg} / \mathrm{m}^{2}$, normal blood pressure, normal resting heart rate (RHR), normal hemoglobin (Hb) and fasting blood glucose (FBG) $<100 \mathrm{mg} / \mathrm{dL}$. All of these research procedures have been approved by the Health Research Ethics Commission of the Faculty of Medicine, Airlangga University, Surabaya number 81/EC/KEPK/FKUA/2020.

Measurement of height using a stadiometer (SECA, Chino, CA). Measurement of body weight, BMI, percentage body fat (PBF), fat mass (FM), free fat mass (FFM) and bone mas (BM) using TANITA (Body Composition Analyzer DC3607601 (2) -1604 FA, TANITA Corporation of America, Inc., USA). Blood pressure was measured twice at a 5 min interval on the right arm using a standard mercury sphygmomanometer (Baumanometer; Baum, Copiague, NY, USA) and recorded as an average of the two readings. Measurement of FBG using ACCU-CHEK (ACCU-CHEK®) Performance, Mannheim, Germany) with $\mathrm{mg} / \mathrm{dL}$ concentration units. Measurement of Hb using Mission Hemoglobin (Mission ${ }^{\circledR}$ Hb Test Strips (Whole Blood), ACON Laboratories, Inc. 10125 Mesa Rim Road, San Diego, CA 92121, USA) with a unit of concentration of g/dL.

Collecting blood was from cubital veins with $4 \mathrm{ml}$ after a 12-hour overnight fasting. Blood was centrifuged for 15 minutes at $3000 \mathrm{rpm}$. Serum was separated and stored at -80 ${ }^{\circ} \mathrm{C}$ for analysis of IGF-1 levels the following day. Blood draws are conducted at 07.00 a.m. Measurement of serum IGF-1 levels using an Enzyme-Linked Immunosorbent Assay (ELISA) kit (Catalog No: E-EL-H0086; Lot No: 5KH3L8GCSC; Elabscience, China) with a standard curve range of 1.56-100 ng/mL and IGF-1 sensitivity level of $0.94 \mathrm{ng} / \mathrm{mL}$.

Statistical analysis used packet statistical software for social science (SPSS) (Chicago, IL, USA). The normality test uses the Kolmogorov - Smirnov test. Correlation test using Pearson product-moment with a significant level $(p \leq 0.05)$. All data are presented as mean \pm SE. 


\section{STRADA Jurnal Ilmiah Kesehatan}

DOI: $10.30994 /$ sjik.v9i2.423

ISSN: 2252-3847 (print); 2614-350X (online)

Vol.9 No.2 November 2020 Page.1041-1046

\section{RESULTS}

The basic profiles of the samples, including age, weight, height, body mass index, percentage body fat, fat mass, free fat mass, systolic blood pressure, diastolic blood pressure, resting heart rate, fasting blood glucose, hemoglobin, insuline-like growth factor1, bone mass are displayed in Table 1 and Table 2.

Table 1. Characteristics of Research Subjects

\begin{tabular}{lccc}
\hline \multicolumn{1}{c}{ Parameters } & n & Mean & Std. Error \\
\hline Age (years) & 30 & 21.56 & 0.13 \\
\hline Weight $(\mathrm{kg})$ & 30 & 72.31 & 1.25 \\
\hline Height $(\mathrm{m})$ & 30 & 1.58 & 0.01 \\
\hline Body mass index $\left(\mathrm{kg} / \mathrm{m}^{2}\right)$ & 30 & 28.98 & 0.29 \\
\hline Percentage body fat $(\%)$ & 30 & 44.54 & 0.57 \\
\hline Fat mass $(\mathrm{kg})$ & 30 & 33.00 & 0.90 \\
\hline Free fat mass $(\mathrm{kg})$ & 30 & 40.77 & 0.61 \\
\hline Systolic blood pressure $(\mathrm{mmHg})$ & 30 & 112.67 & 0.82 \\
\hline Diastolic blood pressure $(\mathrm{mmHg})$ & 30 & 75.00 & 0.93 \\
\hline Resting heart rate $(\mathrm{bpm})$ & 30 & 79.37 & 1.81 \\
\hline Fasting Blood Glucose $(\mathrm{mg} / \mathrm{dL})$ & 30 & 90.16 & 1.20 \\
\hline Hemoglobin $(\mathrm{g} / \mathrm{dL})$ & 30 & 15.23 & 0.25 \\
\hline
\end{tabular}

Table 2. Association between IGF-1 serum levels with bone

\begin{tabular}{lcccc}
\hline Parameter & n & Mean \pm SE & $\boldsymbol{r}$ & p-values \\
\cline { 1 - 3 } IGF-1 $(\mathrm{ng} / \mathrm{mL})$ & \multirow{2}{*}{30} & $1.17 \pm 0.10$ & \multirow{2}{*}{$0.712^{* *}$} & \multirow{2}{*}{0.000} \\
\cline { 1 - 1 } & & & $2.49 \pm 0.06$ &
\end{tabular}

** Significant with $p \leq 0.01$ by Pearson's product-moment

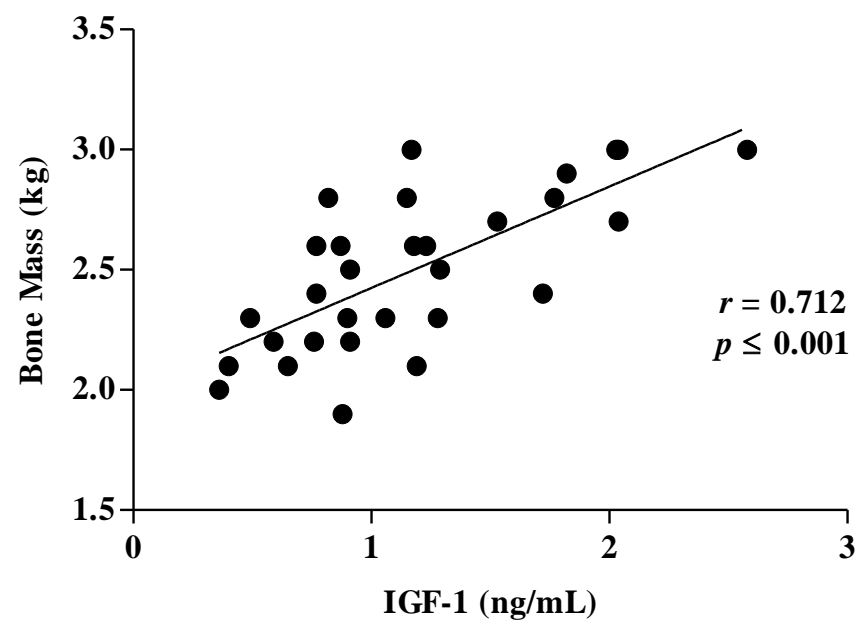

Figure 1. Correlations between IGF-1 levels and bone mass

Based on Table 2 and Figure 1, the results of the Pearson product-moment test show that there was a positive correlation between IGF-1 levels and bone mass $(r=0.712, p \leq$ $0.001)$.

\section{DISCUSSION}

Obesity is a world health problem that must be considered because obesity increases the risk of various chronic diseases such as type 2 diabetes (T2D), hypertension, and cardiovascular disease (CVD) (Gadde et al., 2018). In addition, the condition of obesity also occurs peripheral insulin resistance and hyperinsulinaemia, leading to decreased secretion of Growth Hormone (GH) (Lewitt et al., 2014) and Insulin-like Growth Factors 1 


\section{STRADA Jurnal Ilmiah Kesehatan}

DOI: $10.30994 /$ sjik.v9i2.423

ISSN: 2252-3847 (print); 2614-350X (online)

Vol.9 No.2 November 2020 Page.1041-1046

(Rasmussen et al., 1995). Decreased secretion of growth hormone (GH) and insulin-like growth factor-1 (IGF-1) reduces bone mineral density and increases the risk of fractures, such as fractures of the ankle, leg, humerus and vertebral column (Yakar et al., 2018; Premaor et al., 2014). The relationship of IGF-1 with bone mass or bone density has been studied in adults as well as elderly population. Some researchers have found a positive association of IGF-1 concentrations with bone density (Zhao et al., 2008; Rucker et al., 2004; Langlois et al., 1998; Szulc et al., 2004). The results showed that there was a positive correlation between IGF-1 levels and bone mass (Table 2). These results are in line with the results of research conducted by Chalista et al. (2017) that there is a relationship between IGF-1 levels and low bone mineral density (BMD). Likewise, the results of research conducted by Fornari et al. (2017) concluded that there was a correlation between IGF-1 levels and lumbar and femoral BMD in obese subjects.

Obesity is often associated with abnormalities in GH and IGF-1 secretion (Fornari et $a l ., 2017)$. GH secretion abnormalities can inhibit the liver from secreting IGF-1 (Lewitt et $a l ., 2014)$. GH and IGF-1 have a major role in bone growth and maintaining bone health (Fornari et al., 2017). In general, the effects of GH promoting bone growth appear to be dependent on IGF-1 production. The results of research by Fornari et al. (2017) showed that increased IGF-1 levels were associated with increased BMD in obesity. IGF-1 acts on cartilage, stimulates cell proliferation and synthesis of Deoxyribo Nucleic Acid (DNA), Ribonucleic Acid (RNA), proteins and proteoglycans. IGF-1 is a major component of the organic skeleton matrix and is the most important differentiating factor for osteoblasts. If there is a decrease in the secretion of GH and IGF-1, it can reduce bone mineral density (BMD) and increase the risk of fracture (Ekbote et al., 2015).

IGF-1 is also referred to as somatomedin C, mostly synthesized in the liver and regulated by $\mathrm{GH}$ which has a major role in cell growth and development (Guo et al., 2020), energy metabolism (TaeHo Kim et al., 2015). In addition, IGF-1 also plays a role in maintaining tissue homeostasis, anti-apoptosis, mitogenic, anti-inflammatory, antioxidant and metabolic properties, contributing to skeletal muscle plasticity, maintenance of muscle strength and muscle mass and increased bone mass (Guo et al., 2020; Vitale et al., 2019; Maggio et al., 2013). IGF-1 can be synthesized by endocrine, paracrine and autocrine mechanisms (Stein et al., 2018). IGF-1 synthesis is stimulated by nutrients and GH in the liver and other tissues (Lewitt et al., 2014). GH, through IGF-1 stimulates the proliferation of epiphyseal cartilage so that more space is formed for bone formation and stimulates osteoblast activity (Sherwood, 2014). Osteoblast is a type of bone cell that produces organic matrix in bone. According to Sihombing et al. (2012) osteoblasts make, secrete and precipitate new bone matrix organic elements called osteoid. Osteoblasts contain alkaline phosphatase enzymes which indicate that these cells are not only associated with matrix creation, but also mineralization. When osteoblast activity deposits new bone on the external surface, other cells in the bone, osteoclasts (bone destroyers), dissolve bone tissue on the inner surface beside the marrow cavity (Sherwood, 2014). Osteoclasts are large multinuclear cells located along the surface of the bone where bone resorption, remodeling and repair occur (Sihombing et al., 2012). 


\section{STRADA Jurnal Ilmiah Kesehatan}

DOI: $10.30994 /$ sjik.v9i2.423

ISSN: 2252-3847 (print); 2614-350X (online)

Vol.9 No.2 November 2020 Page.1041-1046

\section{CONCLUSIONS}

Based on the results of the study, it can be concluded that there is a positive correlation between IGF-1 levels and bone mass in obese female. Based on the results of the study, it is recommended that further research be carried out by adding other variables such as growth hormone $(\mathrm{GH})$, insulin, glucose, Insulin-Like Growth Factor Binding Protein 3 (IGFBP3), serum glutamic pyruvic transaminase (SGPT) and serum glutamic oxaloacetic transaminase (SGOT).

\section{REFERENCES}

Ayu, D.S. and Handayani, O.W.K. 2016. Diary Teratas (Terapi Anak Obesitas) dalam Perubahan Perilaku Gizi Siswa Sekolah Dasar. Unnes Journal of Public Health, 5(2): 167-175.

Chalista, S.I., Chong, L.T., Wajda, M. et al. 2017. Association of Insulin-like Growth Factor 1, Bone Mass and Inflammation to Low-Energy Distal Radius Fractures and Fractures Healing in Elderly Women Attending Emergency Care. Orthopedic Surgery, 9(4): 380-385. https://doi.org/10.1111/os.12358.

Dewi, M.C. 2015. Faktor-Faktor yang Menyebabkan Obesitas pada Anak. Majority, 4(8): 53-56.

Ekbote, V.H., Khadilkar, V.V., Shilvant, D.S., et al. 2015. Relation of Insulin-like growth factor 1 and bone parameters in 7-15 years old apparently, healthy Indian children. Indian Journal Endocrinol Metab, 19(6): 770-774.

Fornari, R., Marocco, C., Francomano, D., Fittipaldi, S., Lubrano, C., Bimonte, V.M., Donini, L.M., Nicolai, E., Aversa, A., Lenzi, A., Greco, E.A., and Migliacci, S. 2017. Insulin growth factor-1 correlates with higher bone mineral density and lower inflammation status in obese adult subjects. Eating and Weight Disorders (EWD), 23(3): 375-381. https://doi.org/10.1007/s40519-017-0362-4.

Gadde, K.M., Martin, C.K., Berthoud, H.R. and Heymsfield, S.B. (2018) 'Obesity: Pathophysiology and Management', Journal of the American College of Cardiology, 71(1): 69-84. https://doi.org/10.1016/j.jacc.2017.11.011.

Guo, J., Xie, J., Zhou, B., Gaman, M-A., Kord-Varkaneh, H., Clark, C.C.T., SalehiSahlabadi, A., Li, Y, Han, X., Hao, Y. and Liang, Y. 2020. The influence of zinc supplementation on IGF-1 levels in humans: A systematic review and metaanalysis. Journal of King Saud University - Science, https://doi.org/10.1016/j.jksus.2020.01.018.

Lewitt, M., Dent, M. and Hall, K. 2014. The Insulin-Like Growth Factor System in Obesity, Insulin Resistance and Type 2 Diabetes Mellitus. Journal of Clinical Medicine, 3(4): 1561-1574. https://doi.org/10.3390/jcm3041561.

Langlois JA, Rosen CJ, Visser M, Hannan MT, Harris T, Wilson PW, et al. 1998. Association between insulin-like growth factor I and bone mineral density in older women and men: The Framingham Heart Study. J Clin Endocrinol Metab, 83(12): 4257-4262. https://doi.org/10.1210/jcem.83.12.5308.

Maggio, M., De Vita, F., Lauretani, F., Butto, V., Bondi, G., Cattabiani, C. and Ceda, G.P. 2013. IGF-1, the cross road of the nutritional, inflammatory and hormonal pathways to frailty. Nutrients 5(10): 4184-4205. https://doi.org/10.3390/nu5104184.

Pasquali, R., Casanueva, F., Haluzik, M. Huisteinjn, L.V., Ledoux, S., Monteiro, M.P, Salvador, J., Santini, F., Toplak, H., Dekkers., O.M. 2020. European Society of 


\section{STRADA Jurnal Ilmiah Kesehatan}

DOI: $10.30994 /$ sjik.v9i2.423

ISSN: 2252-3847 (print); 2614-350X (online)

Vol.9 No.2 November 2020 Page.1041-1046

Endocrinology Clinical Practice Gusidline: Endocrine Work-Up in Obesity. European Journal of Endocrinology, 182(1): G1-G32. https://doi.org/10.1530/EJE19-0893.

Premaor, M.O., Comim, F.V., and Compston, J.E. 2014. Obesity and fractures. Arq Bras Endocrinol Metab, 58(5): 470-477. https://doi.org/10.1590/0004-2730000003274.

Rasmussen, M.H.; Hvidberg, A.; Juul, A.; Main, K.M.; Gotfredsen, A.; Skakkebae, N.E.; Hilsted, J. 1995. Massive weight loss restores 24-h growth hormone release profiles and serum insulin-like growth factor-I levels in obese subjects. J. Clin. Endocrinol. Metab, 80: 1407-1415.

Rucker D, Ezzat S, Diamandi A, Khosravi J, Hanley DA. 2004. IGF-I and testosterone levels as predictors of bone mineral density in healthy, community-dwelling men. Clin Endocrinol (Oxf), 60(4): 491-499. https://doi.org/10.1111/j.13652265.2004.02006.x.

Sherwood, L. 2014. Fisiologi Manusia: dari Sel ke Sistem, Edisi 8. Jakarta: Penerbit Buku kedokteran EGC.

Sihombing, I., Wangko, S., Kalangi, S. 2012. Peran Esterogen Pada Remodeling Tulang. Jurnal Biomedik, 4(3): 18-28.

Stein, A.M., Silva, T.M.V., Coelho, F.G.M., Arantes, F.J., Costa, J.L.S., Teodoro, L. and Santos-Galduróz, R.F. 2018. Physical exercise, IGF-1 and cognition A systematic review of experimental studies in the elderly. Dement Neuropsychol, 12(2): 114122. http://dx.doi.org/10.1590/1980-57642018dn12-020003.

Szulc P, Joly-Pharaboz MO, Marchand F, Delmas PD. 2004. Insulin-like growth factor I is a determinant of hip bone mineral density in men less than 60 years of age: MINOS study. Calcif Tissue Int, 74(4): 322-329. https://doi.org/10.1007/s00223-003-0090$\underline{9}$.

TaeHo Kim, Chang, J.S., Kim, H., Lee, K.H. and Kong, I.D. 2015. Intense Walking Exercise Affects Serum IGF-1 and IGFBP3. Journal of Lifestyle Medicine, 5(1): 21-25. http://dx.doi.org/10.15280/jlm.2015.5.1.21.

Vitale, G., Pellegrino, G., Vollery, M. and Hofland, L.J., 2019. ROLE of IGF-1 System in the Modulation of Longevity: Controversies and New Insights From a Centenarians' Perspective. Frontiers in Endocrinology, 10(27): 1-11. https://doi.org/10.3389/fendo.2019.00027.

World Health Organization (WHO). 2014. Global Status Report on Noncommunicable Diseases 2014. Switzerland: WHO Press.

World Health Organization (WHO). Obesity and overweight. 2016. Switzerland: WHO Press Available at: http://www.who.int/mediacentre/factsheets/fs311/en/.

Yakar, S., Werner, H. and Rosen, C.J. 2018. Insulin-like growth factors: actions on the skeleton. Journal of Molecular Endocrinology. 61(1): T115-T137. https://doi.org/10.1530/JME-17-0298.

Zhao HY, Liu JM, Ning G, Zhao YJ, Chen Y, Sun LH, et al. 2008. Relationships between insulin-like growth factor-I (IGF-I) and OPG, RANKL, bone mineral density in healthy Chinese women. Osteoporos Int, 19(2): 221226. https://doi.org/10.1007/s00198-007-0440-y. 